\title{
Prostate cancer incidence and mortality in Navarre (Spain)
}

\section{Incidencia y mortalidad del cáncer de próstata en Navarra (España)}

doi.org/10.23938/ASSN.0123

\author{
J. Etxeberria ${ }^{1,2,3}$, M. Guevara ${ }^{2,3}$, C. Moreno-Iribas ${ }^{2}$, R. Burgui' ${ }^{2,3}$, I. Delfrade ${ }^{2,3}$, Y. Floristan ${ }^{2}$, \\ M. Montesino ${ }^{4}$, E. Ardanaz ${ }^{2,3}$
}

\begin{abstract}
Background. Prostate cancer is one of the most commonly diagnosed malignancies among males worldwide. In this study, overall and age-specific incidence and mortality trends are analyzed in order to present the past and current epidemiological situation of the disease in Navarre (Spain).

Methods. Population-based incidence data from the 19752010 period, provided by the Cancer Registry of Navarre and prostate cancer specific mortality data for 1975-2013, provided by the Spanish Statistical Office, were used in the analysis. Age-standardized incidence and mortality rates, change-points and annual percentage changes (APC) were estimated by joinpoint regression analysis. One-dimensional P-spline models were used to estimate projections up to 2016.

Results. Considerable increases of cancer incidence rates in men aged 45-74 years were observed, with APC of $+4.5 \%$ $(\mathrm{p}<0.001),+9.5 \%(\mathrm{p}<0.001)$ and $+2.4 \%(\mathrm{p}<0.05)$ in the 1975 $1990,1990-2000$ and $2000-2010$ periods, respectively. In the older than 74 age-group, an increase of incidence rates in the 1975-1999 period was registered (APC $+3.3 \%, \mathrm{p}<0.001$ ), followed by a significant decrease up to 2010 (APC $-4.0 \%$, $\mathrm{p}<0.01)$. Mortality rates rose until $1995(\mathrm{APC}+2.2 \%, \mathrm{p}<0.001)$ whereas a decline occurred afterwards up to 2013 (APC $-3.4 \%, \mathrm{p}<0.001)$.

Conclusion. Even though overall prostate cancer incidence rates seem to have stabilized in 2002-2010 in Navarra, trends were different by age groups: increased in men 45-74 years old and decreased in the 75+ year age-group. A decline in mortality rates was observed in both age groups since about 1995. Changes in the use of prostate specific antigen test for screening in oncoming years could affect future prostate cancer trends.
\end{abstract}

Keywords. Prostate Cancer. Incidence. Mortality. Trends. Predictions.

\section{RESUMEN}

Fundamento. A nivel mundial, el cáncer de próstata es uno de los tumores malignos más comúnmente diagnosticados en los hombres. En este estudio, se analizan las tendencias de la incidencia y mortalidad de cáncer de próstata, global y por grupos de edad, para mostrar la situación epidemiológica pasada y actual de la enfermedad en Navarra (España). Método. Para el estudio se utilizaron los casos incidentes diagnosticados entre 1975 y 2010, y las muertes observadas entre 1975 y 2013. Los datos fueron proporcionados por el Registro de Cáncer de Navarra y el Instituto Nacional de Estadística respectivamente. Se calcularon las tasas de incidencia y mortalidad estandarizadas por edad, los puntos de cambio y el porcentaje de cambio anual (PCA) mediante modelos de regresión de joinpoint. Se usaron modelos unidimensionales de P-splines para estimar proyecciones hasta 2016.

Resultados. Se observó un considerable incremento en las tasas de incidencia de cáncer de próstata en hombres de 45-74 años, con PCA de $+4,5 \%(\mathrm{p}<0,001),+9,5 \%(\mathrm{p}<0,001)$ y $+2,4 \%(\mathrm{p}<0,05)$ en los periodos $1975-1990,1990-2000$ y 2000 2010, respectivamente. En el grupo de mayores de 74 se registró un aumento de incidencia en el período 1975-1999 (PCA $+3,3 \%, \mathrm{p}<0,001$ ), seguido de una disminución significativa hasta 2010 (PCA $-4,0 \%, \mathrm{p}<0,01$ ). Las tasas de mortalidad aumentaron hasta 1995 (PCA $+2,2 \%, \mathrm{p}<0,001$ ), mientras que descendieron en el periodo 1995-2013 (PCA -3.4\%, p<0,001).

Conclusión. Aunque las tasas globales de incidencia de cáncer de próstata parecen estabilizarse en 2002-2010 en Navarra, las tendencias fueron diferentes según los grupos de edad, aumentando en los hombres de 45-74 años y disminuyendo en el grupo de mayores de 74 años. Se observó una disminución en las tasas de mortalidad en ambos grupos de edad desde 1995. Cambios en el uso del antígeno prostático específico para cribado en los próximos años podrían afectar las futuras tendencias del cáncer de próstata.

Palabras clave. Cáncer de Próstata. Incidencia. Mortalidad. Estimaciones. Tendencias.
1. Department of Statistics and Operative Research. Institute for Advanced Materials (INAMAT). Public University of Navarra. Pamplona. Spain.

2. Public Health Institute of Navarra. IdiSNA. Pamplona. Spain.

3. CIBER Epidemiología y Salud Pública (CIBERESP). Spain.

4. Complejo Hospitalario de Navarra. Pamplona. Spain.

Recepción: 28/07/2017

Aceptación provisional: 18/10/2017

Aceptación definitiva: 11/12/2017

\section{Correspondencia:}

Eva Ardanaz

Navarra Cancer Registry, Epidemiology Unit, Navarra

Public Health Institute

C/Leyre 15

31006 Pamplona. Spain

E-mail: me.ardanaz.aicua@cfnavarra.es 


\section{INTRODUCTION}

According to the last estimations provided by the International Agency for Research on Cancer (IARC), prostate cancer was the second most common cancer diagnosed in men worldwide in 2012, accounting for $15 \%$ of the cancer cases. Almost $70 \%$ of them occurred in developed regions, where prostate specific antigen (PSA) testing and subsequent biopsy are widespread $^{1}$. The PSA testing has a big effect on incidence rates and therefore the rates can vary among different countries according to the level of PSA implementation. Prostate cancer incidence has increased in recent decades in Europe ${ }^{2}$. As far as mortality is concerned, 307,000 deaths were estimated worldwide in 2012 , placing prostate cancer as the fifth leading cause of death from cancer in men $(6.6 \%$ of the total men deaths). The mortality rates are less variable among different regions worldwide ${ }^{3}$.

As in other European countries, prostate cancer is the most frequent cancer in Spain among men. In 2015, according to the last estimations provided by Galcerán and $\mathrm{col}^{4}, 33,370$ cases were diagnosed in Spain. Prostate cancer mortality is placed as a third cause of death by cancer in men after lung and large bowel cancer ${ }^{4,5}$.

The objective of this study is to provide an in-depth description of trends of prostate cancer in Navarra. To do so, the most up-to-date population-based incidence and mortality data were used. The study is focused on the observed overall and age-specific incidence and mortality trends. Additionally, projections of the incidence and mortality rates are provided up to 2016 as an updated indicator of the burden of this cancer in Navarra.

\section{METHODS}

Data on the incidence of invasive prostate cancer were obtained from the population-based Cancer Registry of Navarra, a region in northern Spain with a population of approximately 640,000 inhabitants in
2010 in which almost $50 \%$ were men. We used the most up-to-date prostate cancer incidence data available in the cancer registry, covering the period 1975-2010. The Navarra Cancer Registry uses multiple sources of information on cancer, including pathology laboratories, hospitals and death certificates. Mortality data from 1975 to 2013 were provided by the Spanish Statistical Office ${ }^{6}$. Population data by 5 -year age groups and gender were obtained from the Statistical Institute of Navarra?

A brief descriptive analysis is provided computing the total number of cases, the average number of cases per year with the standard deviation and the maximum and minimum number for the first and last ten year period of study for the total population and for 45-74 and older than 74 (75+) year age-groups (results for age-group below 45 years were not provided in the descriptive analysis due to the small number of cases).

Annual age-standardized incidence and mortality rates were calculated by the direct method using the new revised European Standard Population 2013 ${ }^{8}$. Trends in incidence and mortality rates were analyzed and change-points and annual percentage changes (APC) were estimated by joinpoint regression analysis using Joinpoint Trend Analysis Software 4.2.0.2 $2^{9,10}$. The estimates and p-values for the annual percentage changes (APC) were estimated as $100^{*}(\exp (\beta)-1)$, where $\beta$ is the slope of the following log-linear regression model $\ln (y)=\beta_{0}+\beta_{1}{ }^{*} t$, where $t$ is the variable time. The p-value of the APC comes from a two-sided test for regression slope which is based on a t distribution ${ }^{9}$. These analyses were carried out for the whole population and for 45-74 year and 75+ year agegroups.

One-dimensional P-spline models were used to estimate projections of the prostate cancer incidence and mortality rates up to 2016. In order to obtain the best estimations, the models were fitted in different periods: 1989-2010, 1990-2010, 19912010 , and so on. Then, a validation process was carried out, in order to assess the predictive performances of models. In this 
Table 1. Prostate cancer incidence and mortality in the first and last ten years of the study period for the total population and by age-groups in Navarra

\begin{tabular}{|c|c|c|c|c|c|}
\hline & Descriptive Analysis & $\begin{array}{l}\text { Incidence } \\
1975-1985\end{array}$ & $\begin{array}{l}\text { Mortality } \\
\text { 1975-1985 }\end{array}$ & $\begin{array}{l}\text { Incidence } \\
2000-2010\end{array}$ & $\begin{array}{r}\text { Mortality } \\
2000-2013\end{array}$ \\
\hline \multicolumn{6}{|c|}{ Total Population } \\
\hline & Total number & 915 & 493 & 4149 & 1138 \\
\hline & $\begin{array}{l}\text { Annual average } \\
\text { (SD) }\end{array}$ & $\begin{array}{c}83 \\
(22)\end{array}$ & $\begin{array}{c}45 \\
(10)\end{array}$ & $\begin{array}{l}377 \\
(38)\end{array}$ & $\begin{array}{l}81 \\
(8)\end{array}$ \\
\hline & $\begin{array}{l}\text { Maximum number of } \\
\text { cases (year) }\end{array}$ & $\begin{array}{c}119 \\
(1985)\end{array}$ & $\begin{array}{c}69 \\
(1985) \\
\end{array}$ & $\begin{array}{c}457 \\
(2008) \\
\end{array}$ & $\begin{array}{c}99 \\
(2000) \\
\end{array}$ \\
\hline & $\begin{array}{l}\text { Minimum number of } \\
\text { cases (year) }\end{array}$ & $\begin{array}{c}50 \\
(1975)\end{array}$ & $\begin{array}{c}33 \\
(1975)\end{array}$ & $\begin{array}{c}331 \\
(2006)\end{array}$ & $\begin{array}{c}66 \\
(2010)\end{array}$ \\
\hline & $\begin{array}{l}\text { Age-standardized rates } \\
(95 \% \mathrm{CI})\end{array}$ & $\begin{array}{c}68 \\
(63-73)\end{array}$ & $\begin{array}{c}41 \\
(37-45)\end{array}$ & $\begin{array}{c}161 \\
(154-169) \\
\end{array}$ & $\begin{array}{c}39 \\
(36-43)\end{array}$ \\
\hline \multicolumn{6}{|c|}{ By Age-group } \\
\hline \multirow[t]{5}{*}{$45-74$} & Total number & 461 & 179 & 2730 & 273 \\
\hline & $\begin{array}{l}\text { Annual average } \\
\text { (SD) }\end{array}$ & $\begin{array}{c}42 \\
(10)\end{array}$ & $\begin{array}{l}16 \\
(3)\end{array}$ & $\begin{array}{l}248 \\
(40)\end{array}$ & $\begin{array}{l}20 \\
(6)\end{array}$ \\
\hline & $\begin{array}{l}\text { Maximum number of } \\
\text { cases (year) }\end{array}$ & $\begin{array}{c}56 \\
(1985)\end{array}$ & $\begin{array}{c}21 \\
(1983)\end{array}$ & $\begin{array}{c}322 \\
(2008)\end{array}$ & $\begin{array}{c}30 \\
(2000)\end{array}$ \\
\hline & $\begin{array}{l}\text { Minimum number of } \\
\text { cases (year) }\end{array}$ & $\begin{array}{c}28 \\
(1975)\end{array}$ & $\begin{array}{c}13 \\
(1977)\end{array}$ & $\begin{array}{c}193 \\
(2002)\end{array}$ & $\begin{array}{c}11 \\
(2010)\end{array}$ \\
\hline & $\begin{array}{l}\text { Age-standardized } \\
\text { truncated rates }{ }^{\mathrm{a}}(95 \% \mathrm{Cl})\end{array}$ & $\begin{array}{c}69 \\
(64-74)\end{array}$ & $\begin{array}{c}27 \\
(24-30)\end{array}$ & $\begin{array}{c}278 \\
(298-288)\end{array}$ & $\begin{array}{c}22 \\
(19-25)\end{array}$ \\
\hline \multirow[t]{5}{*}{$75+$} & Total number & 453 & 312 & 1418 & 865 \\
\hline & $\begin{array}{l}\text { Annual average } \\
\text { (SD) }\end{array}$ & $\begin{array}{c}41 \\
(13)\end{array}$ & $\begin{array}{l}28 \\
(9)\end{array}$ & $\begin{array}{l}129 \\
(12)\end{array}$ & $\begin{array}{l}61 \\
(5)\end{array}$ \\
\hline & $\begin{array}{l}\text { Maximum number of } \\
\text { cases (year) }\end{array}$ & $\begin{array}{c}63 \\
(1985)\end{array}$ & $\begin{array}{c}50 \\
(1985)\end{array}$ & $\begin{array}{c}154 \\
(2002)\end{array}$ & $\begin{array}{c}70 \\
(2008)\end{array}$ \\
\hline & $\begin{array}{l}\text { Minimum number of } \\
\text { cases (year) }\end{array}$ & $\begin{array}{c}21 \\
(1975)\end{array}$ & $\begin{array}{c}18 \\
(1975)\end{array}$ & $\begin{array}{c}111 \\
(2006)\end{array}$ & $\begin{array}{c}53 \\
(2007)\end{array}$ \\
\hline & $\begin{array}{l}\text { Age-standardized } \\
\text { truncated rates }^{\mathrm{a}}(95 \% \mathrm{Cl})\end{array}$ & $\begin{array}{c}471 \\
(458-483)\end{array}$ & $\begin{array}{c}345 \\
(335-356)\end{array}$ & $\begin{array}{c}649 \\
(634-664)\end{array}$ & $\begin{array}{c}334 \\
(324-343)\end{array}$ \\
\hline
\end{tabular}

SD: standard deviation; ${ }^{\text {a }}$ annual mean; $95 \% \mathrm{CI}$ : confidence interval; $75+: 75$ years or older

process, the mean absolute relative bias (MARB) was computed for each fitting. This measure indicates which time period is the best to provide the best predictions. Values close to cero indicate good performance of the model ${ }^{11}$. The MARB indicated that $1999-2010$ period was the best to predict incidence rates and 1996-2013 period was the best to predict mortality rates. The mean MARB values for incidence and mortality predictions where 0.0484 and 0.0759 .

\section{RESULTS}

A total of 7,707 incident cases of invasive prostate cancer were recorded in the twenty-five year period and 1,629 prostate cancer deaths occurred in the twenty-eight year period analysed. Incidence and mortality in the first and the last ten years of the study period are shown in table 1 . The annual number of incident cases markedly increased between these two periods from 83 to 377 . By age-groups the absolute number 


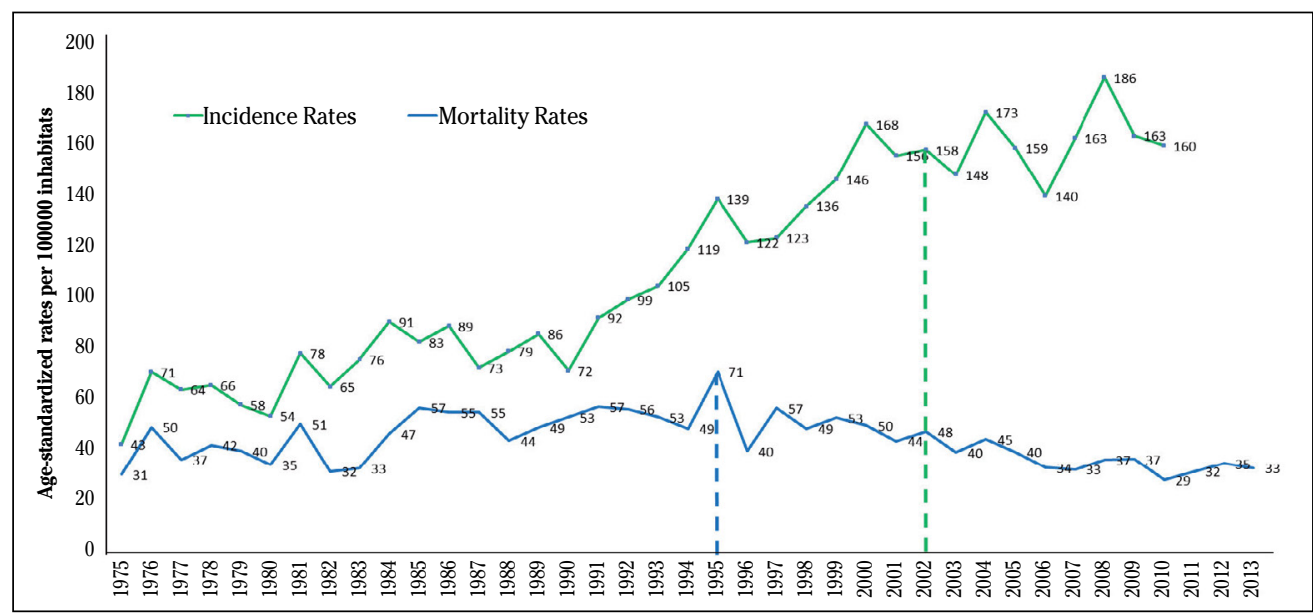

Figure 1. Trends and change points in age-standardized incidence and mortality rates of prostate cancer in Navarra.

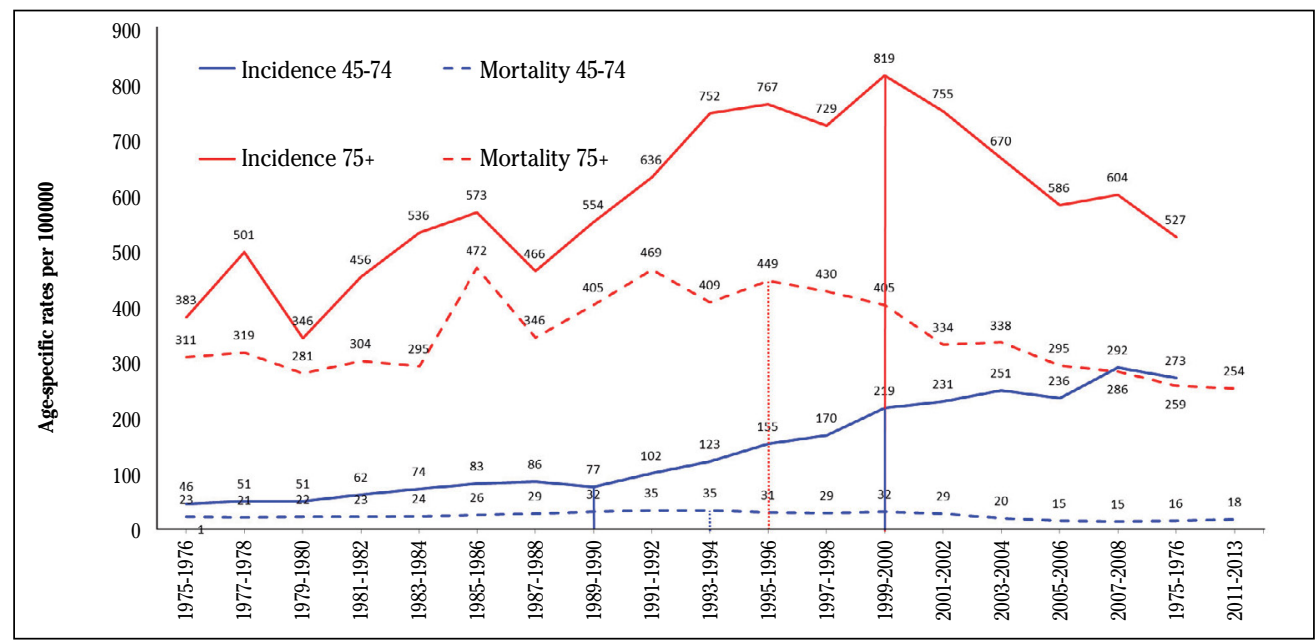

Figure 2. Trends and change points in age-standardized incidence and mortality rates of prostate cancer by age-groups (45-74 and 75 or older) in Navarra.

of incident cases rose from 42 to 248 in men 45-74 years old and from 41 to 129 in men aged $75+$. Similarly, an increase in the absolute number of prostate cancer deaths was observed between the two periods.

Trends in age-standardized incidence and mortality rates for the whole population are shown in figure 1 . Prostate cancer incidence rates increased by $4.1 \%$ annually between 1975 and $2002(\mathrm{p}<0.001)$ followed by a stabilization of rates until 2010 (APC $+0.7 \%, \mathrm{p}=0.726$ ); therefore, a change point in incidence was estimated in 2002 . On the other hand, the mortality rates showed an increase of $2.2 \%(\mathrm{p}<0.001)$ per year up to 1995, while a decreasing trend (APC $-3.4 \%$, $\mathrm{p}<0.001$ ) was observed up to 2013 .

Age-specific incidence rate trends for 45-74 and 75+ age-groups are shown in figure 2 . An increase in incidence was observed in the 45-74 age-group over the studied period. More precisely, incidence rates increased by $4.5 \%$ annually from 1975 to $1990(\mathrm{p}<0.001)$, then by $9,6 \%$ per year up to $2000(\mathrm{p}<0.001)$, followed by a less pronounced increase up to 2010 (APC $+2.4 \%$, 

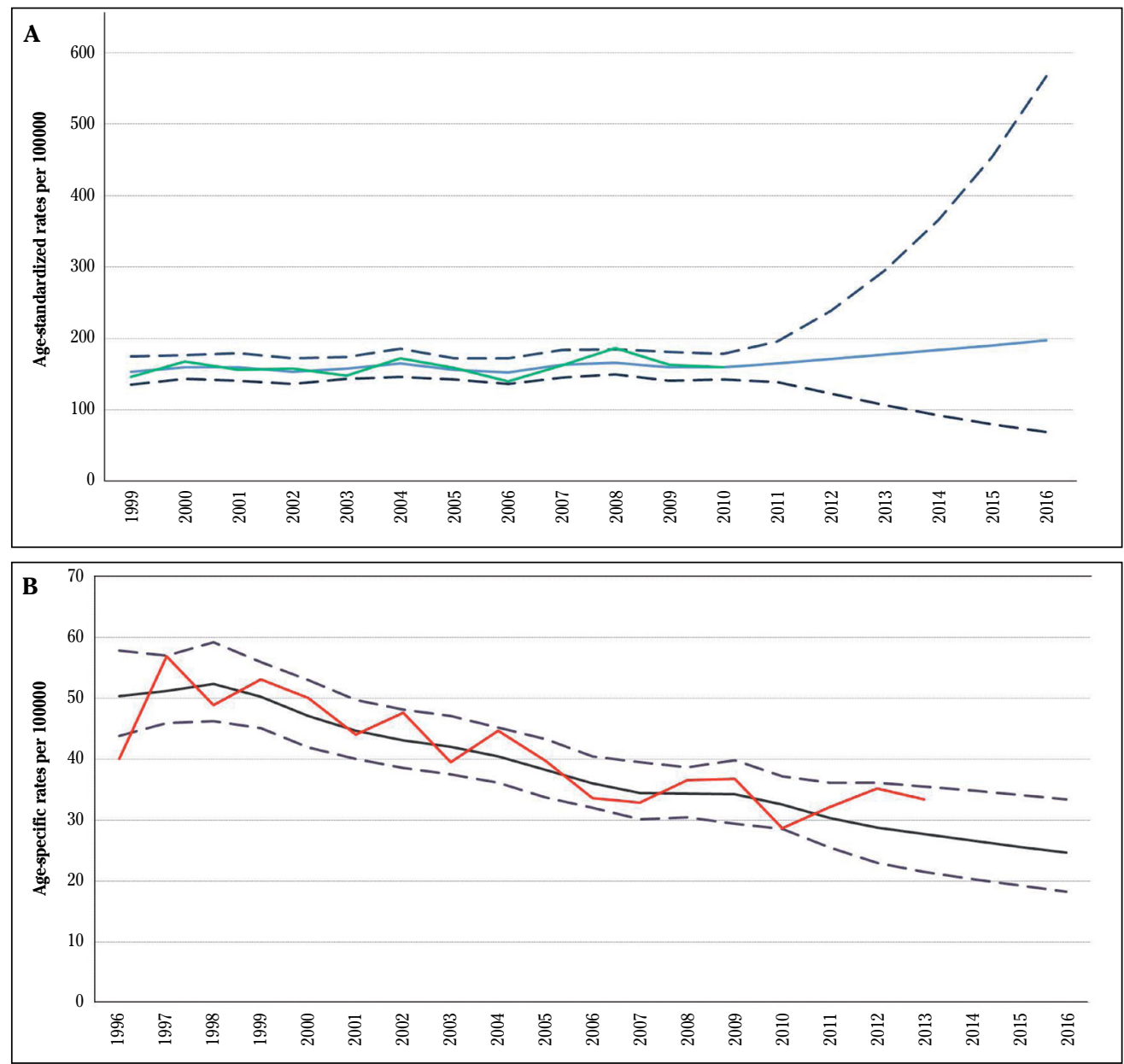

Figure 3. Projections of prostate cancer incidence (A) and mortality (B) rates up to 2016 and their corresponding $95 \%$ prediction intervals (dashed lines).

$\mathrm{p}=0.023)$. In the 75+ age-group, an increase of rates was observed between 1975 and 1999 (APC $+3.3 \%, \mathrm{p}<0.001$ ), followed by a significant decrease (APC $-4.0 \%, \mathrm{p}<0.01$ ). Mortality trends were quite similar in the two age-groups. The mortality rates for the 45-74 age-group increased up to $1994(2.9 \%$ per year, $\mathrm{p}<0.01$ ), afterwards a significant decline was observed up to 2013 (APC $-4.7 \%, \mathrm{p}<0.001)$. In the $75+$ age-group mortality rates increased up to 1995 (2.5\% per year, $\mathrm{p}<0.001$ ) and then declined up to 2013 (APC $-3.6 \%$ per year, $\mathrm{p}<0.001$ ).

Estimated projections for prostate cancer incidence and mortality up to 2016 based on one-dimensional P-spline models were represented in figure 3 . It is estimated a slight increase of incidence rates while the reduction of mortality would have continued up to 2016 .

\section{DISCUSSION}

In this study, prostate cancer incidence and mortality trends were analyzed throughout a large period in Navarra. In recent years, even though overall incidence rates stabilized from 2002 to 2010, trends were different between the two age groups 
analyzed: rates increased in 45-74 years old age-group and decreased in the older agegroup. A decline in mortality was observed in both age groups since about 1995 .

Overall changes in incidence and mortality observed in Navarra are similar to those reported in Spain and other European countries ${ }^{5,12-14}$. In Spain, incidence rates increased by $1.3 \%$ per annum from 1975 to 1990 , and even more sharply thereafter (7.3\% per annum) up to $2004^{13}$. The sharp rise in incidence after the early 1990 s observed also in countries such as the United States and other European countries coincided with the introduction of PSA testing $^{15-18}$. Some authors have suggested that the increase of incidence may also be attributed to the more frequent use of transurethral resection of the prostate and invasive diagnostic procedures such as random biopsies ${ }^{16}$.

An outstanding finding in Navarra incidence trends, not reported previously in Spain, is the decrease of the cancer incidence observed in men $75+$ years old. This decline in the incidence has been observed in men older than 80 years in the United Kingdom $^{19}$, as well as in the United States ${ }^{20}$. In this last country, a recent study showed a decline in the incidence not only in the older but also in younger age groups since 2011 , and according to the authors this decrease could be related to the decreased PSA screening after the publication of the results from two large clinical trials: the prostate, lung, colorectal and ovarian (PLCO) cancer screening trial and the European randomized study of screening for prostate cancer (ERSPC) ${ }^{21}$.

Several authors have discussed about different changes in care of prostate cancer patients and their contribution in the decline of prostate cancer mortality: increase in the use of higher-definition computed tomography and ultrasonography for a better diagnosis and staging, more refined surgical approaches, introduction of antiandrogen therapies, chemotherapy and new modes of radiation treatment, and the use of PSA for diagnosis and monitoring to detect locally recurrent or metastatic disease before it becomes symptomatic ${ }^{22,23}$.
Based on the observed period, incidence rates are projected up to 2016 . However, since the prostate cancer incidence is very sensitive to PSA screening, changes in screening practices could affect markedly these predictions. Currently, the Sociedad Española de Medicina Familiar y Comunitaria (semFYC), the Canadian Task Force on Preventive Health, the UK National Screening Committee and the US Preventive Services Task Force, among other scientific institutions, do not recommend PSA-based systematic screening for prostate cancer in asymptomatic population. These recommendations are supported by studies measuring pros and cons of early detection and subsequent treatment of localized prostate cancer. Additionally, there are no evidences indicating that prostate cancer patients diagnosed by screening have better outcomes than those diagnosed from clinical symptoms. Furthermore, it should be taken into account the important risks associated with PSA screening, including the risks of overdiagnosis and overtreatment ${ }^{24}$.

In conclusion, overall prostate cancer incidence rates seem to have stabilized in 2002-2010 in Navarra, however, trends were different by age groups: increased in men 45-74 years old whereas decreased in the $75+$ year age-group. A decline in mortality rates was observed in both age groups since about 1995. Changes in the use of PSA test for screening in oncoming years could affect future prostate cancer trends.

\section{REFERENCES}

1. Ferlay J, Soerjomataram I, Dikshit R, Eser S, MaTHERS C, REBELo M et al. Cancer incidence and mortality worldwide: sources, methods and major patterns in GLOBOCAN 2012. Int J Cancer 2015; 136: E359-E386.

2. Bray F, Lortet-Tieulent J, Ferlay J, Forman D, AuVINEN A. Prostate cancer incidence and mortality trends in 37 European countries: an overview. Eur J Cancer 2010; 46: 3040-3052.

3. Forman D, Bray F, Brewster DH, Gombe Mbalawa C, Kohler B, PIÑERos M et al. Cancer incidence in five continents, Vol. X. IARC. Scientific Publication N. 164. 2014; Lyon: International Agency for Research on Cancer. 
4. Galceran J, Ameijide A, Carulla M, Mateos A, Quirós JR, RoJAs D et al. Cancer incidence in Spain, 2015. Clin Transl Oncol 2017; 19: 799-825.

5. Ferlay J, Steliarova-Foucher E, Lortet-Tieulent J, Rosso S, Coebergh JWW, Comber H et al. Cancer incidence and mortality patterns in Europe: estimates for 40 countries in 2012. Eur J Cancer 2013; 49: 1374-1403.

6. Spanish Statistical Office (INE). Datos de mortalidad 1975-2013. http://www.ine.es/jaxi/ menu.do?type $=$ pcaxis $\&$ path $=\% 2 \mathrm{Ft} 40 \% 2 \mathrm{Fcn}-$ pa02\%2F\&file=inebase \&L=1 Consultado el 31 de marzo de 2017.

7. Instituto de Estadística de Navarra (IEN). Cifras de población por municipio. https:// www.navarra.es/AppsExt/GN.InstitutoEstadistica.Web/consulta.aspx?TC=3 Consultado el 31 de marzo de 2017.

8. Uk Government, Office for National StatisTics. Revised European Standard Population 2013. http://www.ons.gov.uk/ons/ guide-method/user-guidance/health-and-lifeevents/revised-european-standard-population-2013-2013-esp-/index.html Consultado el 31 de marzo de 2017.

9. Kim HJ, Fay MP, Feuer EJ, Midthune DN. Permutation tests for joinpoint regression with applications to cancer rates. Stat Med 2000; 19 : 335-351 (correction: 2001; 20: 655).

10. National Cancer Institute, US Department of Health and Human Services. Joinpoint Regression Program, Version 4.3.1.0. April 2016. https://surveillance.cancer.gov/joinpoint/

11. Ugarte MD, Goicoa T, Etxeberria J, Militino AF. Projections of cancer mortality risks using spatio-temporal P-spline models. Stat Methods Med Res 2012; 21: 545-560.

12. Ardanaz E, Moreno-Iribas C, Pérez de Rada M, EzPonda C, Floristán Y, Navaridas $\mathrm{N}$ et al. Incidencia y mortalidad por cáncer en Navarra, 1998-2002. Evolución en los últimos 30 años. An Sist Sanit Navar 2008; 30: 245-270.

13. Larrañaga N, Galceran J, Ardanaz E, Franch P, Navarro C, SÁnchez MJ et al. Prostate cancer incidence trends in Spain before and during the prostate-specific antigen era: impact on mortality. Ann Oncol 2010; 21 (Suppl 3): iii83-iii89.

14. Ugarte MD, Goicoa T, Etxeberria J, Militino, AF. A P-spline ANOVA type model in space-time disease mapping. Stoch Environ Res Risk Assess $2012 ; 26$ : 835-845.
15. Etzioni R, Penson DF, Legler JM, Di Tommaso D, Boer R, GANN PH et al. Overdiagnosis due to prostate-specific antigen screening: lessons from U.S. prostate cancer incidence trends. J Natl Cancer Inst 2002; 94: 981-990.

16. Chen C, Naidoo N, Yang Q, Hartman M, VerKOOIJEN HM, LoY EY et al. A comparative population-based study of prostate cancer incidence and mortality rates in Singapore, Sweden and Geneva, Switzerland from 1973 to 2006. BMC Cancer 2012; 12: 222. doi: 10.1186/1471-2407-12-222.

17. Hussain S, Gunnell D, Donovan J, McPhail S, Hamdy F, Neal D. Secular trends in prostate cancer mortality, incidence and treatment: England and Wales, 1975-2004. BJU Int 2008; 101: 547-555.

18. Pashayan N, Powles J, Brown C, Duffy SW. Excess cases of prostate cancer and estimated overdiagnosis associated with PSA testing in East Anglia. Br J Cancer 2006; 95: 401-405.

19. Cancer Research UK. Prostate cancer (C61): 1993-2014. http://www.cancerresearchuk. org/sites/default/files/cstream-node/inc asr_uk_prostate_I14.pdf. Consultado el $1 \overline{3}$ de noviembre de 2017.

20. Jemal A, Fedewa SA, Ma J, Siegel R, Lin CC, BraWLEY $\mathrm{O}$ et al. Prostate cancer incidence and PSA testing patterns in relation to USPSTF screening recommendations. JAMA 2015; 314: 2054-2061.

21. Herget KA, Patel DP, Hanson HA, Sweeney C, LOWRANCE WT. Recent decline in prostate cancer incidence in the United States, by age, stage, and Gleason score. Cancer Med 2016; 5: 136-141.

22. Dickinson J, Shane A, Tonelli M, Gorber SC, Joffres M, SingH $\mathrm{H}$ et al. Trends in prostate cancer incidence and mortality in Canada during the era of prostate-specific antigen screening. CMAJ open 2016; 4: E73-E79.

23. Cayuela A, Rodríguez-Domínguez S, Martín EV, CANDAU RB. Cambios recientes en la mortalidad por cáncer de próstata en España: estudio de tendencias en el período 1991-2005. Actas Urol Esp 2008; 32: 184-189.

24. Marzo-Castillejo M, Bellas-Beceiro B, Vela-Vallespín C, Nuin-Villanueva M, Bartolomé-Moreno C, Melús-Palazón E et al. Recomendaciones de prevención del cáncer. Aten Primaria 2016; 48: 39-59. 
